\title{
Amino Acid Composition in Fillets of Mirror Crossbreds Common Carp (Cyprinus carpio, Linnaeus 1758)
}

\author{
Hana Buchtová1, Zdeňka Svobodová ${ }^{1,2}$, Martin Kocour ${ }^{2}$, Josef Velíšek ${ }^{2}$ \\ ${ }^{1}$ University of Veterinary and Pharmaceutical Sciences, Brno, Czech Republic \\ ${ }^{2}$ University of South Bohemia in České Budějovice, Research Institute of Fish Culture \\ and Hydrobiology, Vodňany, Czech Republic
}

Received August 19, 2008

Accepted February 9, 2009

\begin{abstract}
The aim of the study was to determine the amino acid composition in fillet proteins of newly bred mirror carp lines. In the experiments, the Hungarian mirror carp (M2) were used at the maternal position. These were crossed with male carp of other breeds (top crossing). They included the Hungarian mirror carp (M2) for the production of a pure line, the Hungarian mirror line (L15), the Israeli breed (DOR70) and the Northern mirror carp (M72). The scaly hybrid of the Ropsha (ROP) and the Tataj (TAT) carp was used as a control. In view of the genetic specification of the carp groups monitored, numerous differences $(P<0.01$ and $P<0.05)$ in the composition of specific amino acids (EAA: Val, Leu, Lys, Arg, Met; NEAA: Asp, Glu, Tyr) and their total amounts $\left(\mathrm{EAA}_{\text {sum }}, \mathrm{NEAA}_{\text {sum }}\right)$ were found between the scaly control (ROP $\times$ TAT) and the pure line M2. Higher amino acid values were found in control hybrids. Compositions of amino acids in fillet muscle tissue of experimental mirror carp (M2 $\times$ L15, M2 $\times$ DOR70) were practically identical. Compared to the controls $($ ROP $\times$ TAT), these carp groups contained less $(P<0.01)$ Leu, Lys, Arg and Glu. A composition of amino acids statistically comparable with the controls $(\mathrm{ROP} \times \mathrm{TAT})$ was found only in the M2 $\times$ M72 hybrid with the exception of Glu, which was found in smaller quantities in this hybrid $(P<0.01)$. In terms of sex differences, the greatest amounts of amino acids were found in fillets of male ROP $\times$ TAT controls, the amino acid compositions in male and female mirror carp were practically the same. In this type of evaluation, i.e. regarding amino acid composition, the only carp comparable with the ROP $\times$ TAT control is the M2 $\times$ M72 hybrid.
\end{abstract}

Fish meat, carp, amino acid, chemical indicator, quality

In the Czech Republic, the common carp (Cyprinus carpio, Linnaeus 1758) of the family Cyprinidae is considered as economically the most important fresh-water fish species reared for commercial purposes. Typically extensive to semi-intensive in character, carp production is based on the farming of F1 generation fry obtained from controlled reproduction of sexually mature genetically specified generation carp. The breeds of mirror carp used in the Czech Republic for this purpose are of the original Hungarian line denominated as M2, or a hybrid between M2 and the Northern Mirror Carp breed referred to as M72 (Czech origin). In scaly carp, the most frequent generation fish is the Třeboňský scaly carp, Mariánsko-Lázeňský scaly carp (both breeds of Czech origin), or a hybrid between the Ropsha carp (ROP) of Russian origin and the Tataj carp (TAT) of Hungarian origin. Production of carp at smaller fish farms relies also on the fry from local carp populations that have been given names derived from the nearby villages or locations, and which are often not unambiguously genetically specified. Carp production utilizes natural foods supplemented with cereals and complementary feed mixes.

Carp breeding receives systematic attention with the objective to enhance useful characteristics and production efficiency (Linhart et al. 2002; Kocour et al. 2005a; Kocour et al. 2007). Production efficiency of different genetic groups of carp (breeds, lines, crossbreds) is regularly tested at both the level of production variables and slaughter value (Gela and Linhart 2000; Gela et al. 2003; Kocour et al. 2005b; Buchtová et

Address for correspondence:

Doc. MVDr. Hana Buchtová, Ph.D.

University of Veterinary and Pharmaceutical Sciences Brno

Department of Meat Hygiene and Technology

Palackého 1-3

61242 Brno, Czech Republic

Fax: +420541321230

E-mail: buchtovah@vfu.cz

http://www.vfu.cz/acta-vet/actavet.htm 
al. 2006ab) and the level of chemical composition of edible parts and nutritional value (Buchtová et al. 2007ab; Buchtová et al. 2008).

Experimental studies evaluating common carp have recently been extended to include specific issues of food safety regarding the marketing of this most common freshwater fish (Ježek and Buchtová 2007). The factors considered include carp fillet shelf-life under various experimental packaging conditions (vacuum, modified atmosphere) and storage conditions with the objective to define physical and chemical indicators and their concrete numerical values that are decisive for shelf-life period determination.

In accordance with systematic research into the above issues in the Czech Republic, this paper presents the results of a study on amino acid composition of fillet proteins of the M2 breed and its mirror hybrids (M2 $\times$ L15, M2 $\times$ DOR70, M2 $\times$ M72) compared to the control hybrid ROP $\times$ TAT, which is commonly farmed for commercial purposes.

\section{Materials and Methods}

The performance test of mirror types of the common carp was started in 2003 by the fishfarming company Rybníkáŕství Tábor, when fish in the $\mathrm{K}_{0}$ stage were stocked. The test was concluded at the end of the 2005 vegetation period, in which the fish reached harvest size. The fish were tested in ponds and, to guarantee the objectivity of results of performance, growth and survival, an internal control group with a different scaling phenotype was used (Linhart et al. 2002; Kocour et al. 2005ab, 2007). In the experiments, the Hungarian mirror carp (M2) were used at the maternal position. These were crossed with male carp of other breeds (top crossing). These breeds were the Hungarian mirror carp (M2) for pure breed production, Hungarian mirror line (L15), the Israeli breed (DOR70) and the Northern mirror carp (M72). The scaly hybrid of the Ropsha (ROP) and the Tataj (TAT) carp was used as a control. The fish were reared under standard conditions for pond fish farming in the CR with semi-intensive management. Fish had their natural diet available in the ponds (plankton, benthos) for growth over three vegetation seasons. Fish usually do not feed in the winter (November-February) period. In the first vegetation season, the fish were fed with supplementary feed mix KP1 three times a week, starting when they were 2 months old. In the second vegetation period, the supplementary feed mix was replaced with uncrushed wheat, which was also fed to the fish in the third vegetation period. The supplementary feed was fed 3 times weekly throughout the test. Daily feeding rate was calculated based on the water temperature, oxygen level and the occurrence of natural food according to the recommended directive for fish farmers (unpublished data). The rate of supplementary feeding on the total weight gain of fish during the whole rearing period was estimated approximately on the basis of applied feed and the feed conversion ratio (4 for grain and 3 for KP1) at $40 \%$. During the test (before and after each vegetation period), data on growth (weight) and survival of the fish (\% survival) were recorded.

The final evaluation of the test was made at the end of the 2005 vegetation period in three-year-old fish $\left(\mathrm{K}_{3}\right)$. From the pond with the highest mean fish weight, 40 carp from each of the 5 groups (i.e. the ROP $\times$ TAT control, M2 pure line, experimental hybrid M2 $\times$ L15, M2 $\times$ DOR70, M2 $\times$ M72) were chosen at random (a total of 200 fish). Fish carcasses were dressed according to Gela and Linhart (2000) at the University of South Bohemia, Research Institute of Fish Culture and Hydrobiology, Vodňany, Czech Republic.

The variables monitored included the fish live weight (FLW), the weight of the two skinned fillets of each of the fish $\left(\mathrm{FW}_{\mathrm{abs}}\right)$, the gonad weight $(\mathrm{GW})$ and the gonad-to-total weight ratio ( $\mathrm{FW}_{\mathrm{rel}}$, GSI).

To study amino acid composition in fish meat, 5 male carp and 5 female carp fillets were chosen at random from each of the groups (a total of 50 fillets). The AAA was used to determine the composition (in \%) of the amino acids found.

To prepare samples for amino analysis, $0.5 \mathrm{~g}$ from each mixed sample with a $0.0001 \mathrm{~g}$ accuracy (PRECISA 240 A, France) were used (homogenization: Moulinex ILLICO Y92, Ireland). The samples were prepared by acid hydrolysis $\left(\mathrm{HCl}=6 \mathrm{~mol}^{-1} \mathrm{l}^{-1}\right)$ for $24 \mathrm{~h}$ at $110^{\circ} \mathrm{C}$. The amino acid assay was performed on the AAA 400 automatic amino acid analyzer (INGOS a.s. Praha, CR). For their separation, sodium-citrate elution buffers in a chromatographic column with catex (OSTION LG ANB, CR) were used. After colour reaction with the ninhydrin, separated amino acids were detected in a flow photometer. AMIK software 3.0 (CR) was used to calculate retention times and areas of individual amino acid peaks, and to process data. Reagents necessary for the preparation of samples, buffers and AAA operation were supplied by the amino analyzer manufacturer. Solutions of standard amino acid mixtures also supplied by the AAA manufacturer were used as external amino acid standards.

The abundance of each of the amino acids was then calculated in grams per $1 \mathrm{~kg}$ fillet weight $\left(\mathrm{g} \cdot \mathrm{kg}^{-1}\right)$. For this calculation, laboratory determination of the net protein content in fillets was used. The net protein content was determined as the amount of organically bound nitrogen (recalculating coefficient $f_{1}=6.25$ ) after precipitation of the samples with hot tannin solution (Davídek et al. 1977) using the semiautomatic analyzer Kjeltec 2300 (FOSS Analytical AB, Sweden) and procedures recommended by the manufacturer (AN 300).

Basic statistical values (means, S.D. and S.E.) of the variables investigated were processed in Excel 97. 


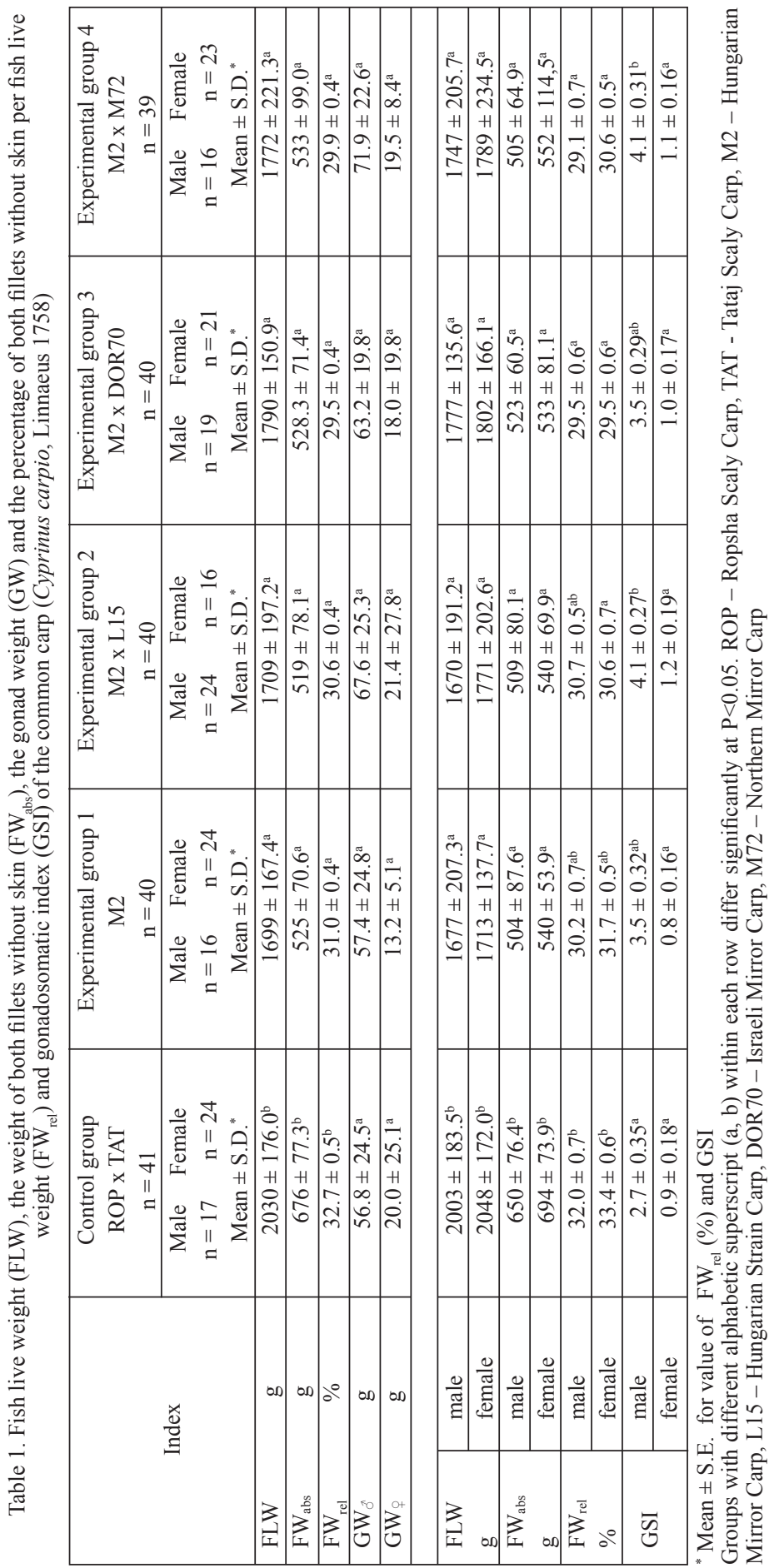

Significance was evaluated using the multifactorial analysis of variance ANOVA (for indicators FLW, $\mathrm{FW}_{\text {abs }}$ and GW) and ANCOVA $^{\text {abs }}$ (for indicator $\mathrm{FW}_{\text {rel }}$ and GSI) Statistica 7.0 ${ }^{\text {rel }}$ (StatSoft CR, s.r.o., Praha, Czech Republic).

\section{Results}

The live weight (g), fillet weight without skin, gonad weight and ratios of those values to the total weight in the carp groups studied including sex dependence (female carp vs. male carp) are given in Table 1. The highest $(P<$ 0.05 ) values of the indicators monitored (FLW: $2030 \pm 176.0$ $\mathrm{g}, \mathrm{FW}_{\mathrm{abs}}: 676 \pm 77.3$ $\mathrm{g}, \mathrm{FW}_{\text {rel }}^{\mathrm{abs}}: 32.7 \pm 0.5$ $\%$ ) were found in the scaly control group ROP $\times$ TAT. Values of the same ones (i.e. FLW, $\mathrm{FW}_{\mathrm{abs}}$, $\mathrm{FW}_{\text {rel }}$ ) ascertained in experimental mirror carp groups (M2, M2 × L15, M2 $\times$ DOR70, M2 × M72) were generally lower and mutually comparable.

FLW and $\mathrm{FW}_{\mathrm{abs}}$ values were higher in female carp than in their male counterparts. Inside groups $(\mathrm{ROP} \times \mathrm{TAT}$, M2, M2 × L15, M2 × DOR70, M2 × M72), sex-based differences (female carp v. male carp) in these values were not significant. 


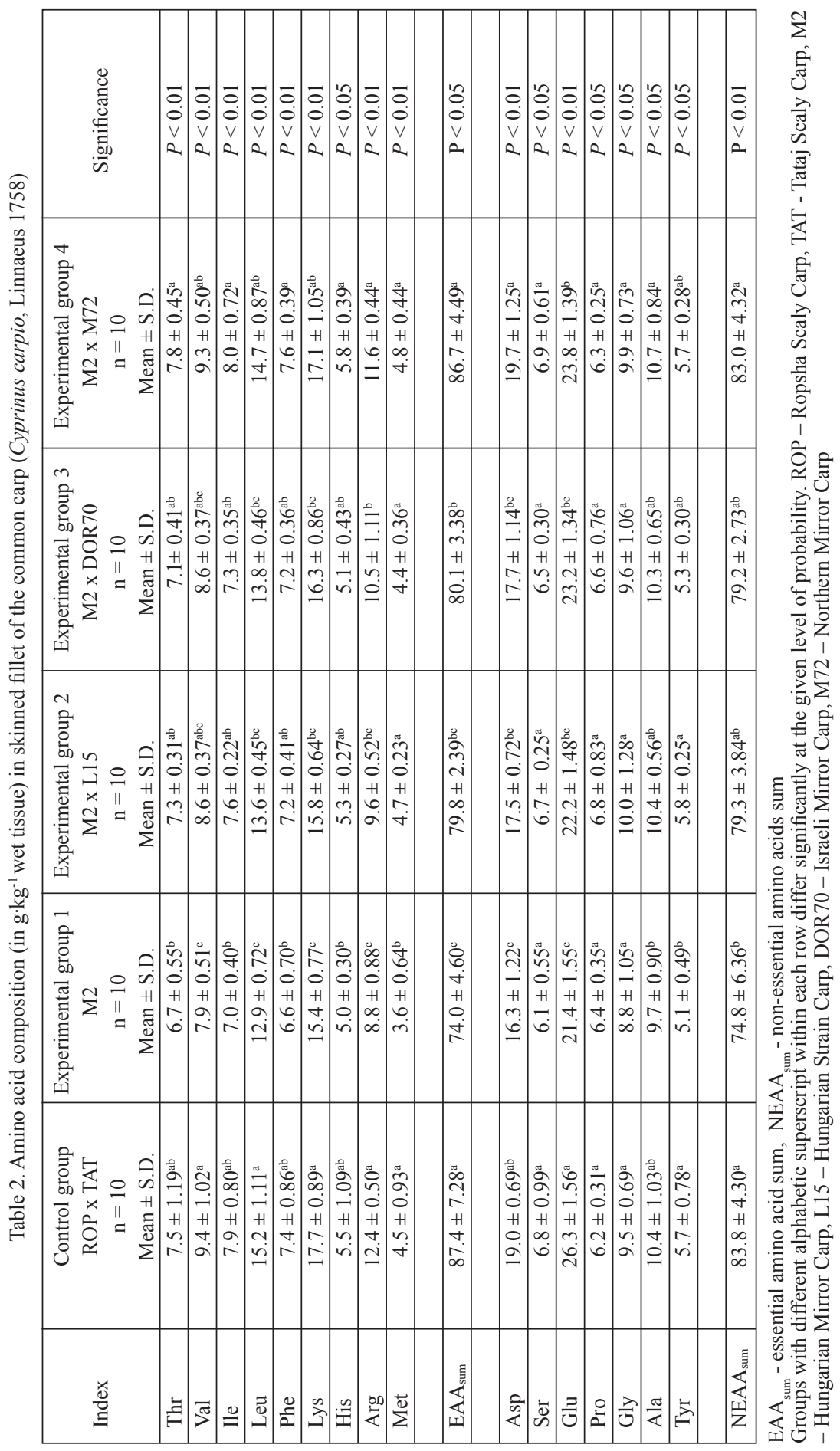


From among male and female carp of different types of hybrids (or lines), the weight of males and females of the ROP $\times$ TAT hybrid was the highest $(P<0.05)$.

The evaluation of the $\mathrm{FW}_{\text {rel }}$ in dependence on individual groups was not clear-cut. Fillet ratios of $\mathrm{ROP} \times$ TAT males, M2 line males and M2 $\times$ L15 hybrid males were comparable, and so were fillets of ROP $\times$ TAT hybrid females and M2 line female carp. In other cases, significant differences in values between the control (ROP $\times$ TAT hybrid males or females) and the experimental groups $(\mathrm{M} 2 \times \mathrm{DOR} 70$ and M2 $\times$ M72 hybrid males or M2 $\times$ L15, M2 $\times$ DOR70 and M2 $\times$ M72 hybrid females) of carp were found.

There were no significant differences in soft roe weights $(\mathrm{GW} \hat{\jmath})$ or hard roe weights $(\mathrm{GW}$ ) between different types of hybrids (or lines). Within individual groups, gonad weight and the GSI value in male carp were in all cases higher $(P<0.05)$ than the gonad weight and the GSI value in female carp.

The composition of amino acids $(\mathrm{g})$ per $1 \mathrm{~kg}$ of skinned fillets in the monitored groups of the common carp irrespective of sex is given in Table 2 . We found the same amino acid compositions in fillets of the control scaly hybrid (ROP $\times$ TAT) and in fillets of the M2 $\times$ M72 mirror carp with the exception of Glu, which was found in smaller quantities in M2 $\times$ M72 carp fillets $(P<0.01)$. Lower levels of Glu and other three amino acids $(P<0.01)$, i.e. Leu, Lys and Arg, were also found in other two experimental hybrids (M2 $\times$ L15, M2 $\times$ DOR70). Compared to the control ROP $\times$ TAT fillets, we found most differences in amino acid composition in the pure line M2 fillets, which beside lower $(P<0.01)$ levels of Glu, Leu, Lys and Arg contained less Val, Met, Asp $(P<0.01)$ and Tyr $(P<0.05)$ amino acids. On the other hand, levels of other 8 amino acids, i.e. Thr, Ile, Phe, His, Ser, Pro, Gly and Ala, were practically identical in fillets of all the carp groups studied. Differences in the content of specific amino acids were the reason for differences in overall contents of essential amino acids EAA sum $_{\text {and non-essential amino acids NEAA }}$ sum. The most abundant amino acids in carp fillets in the group monitored were Glu, Asp, Leu and Arg.

Sex dependence in amino acid composition was clearly demonstrated only in scaly ROP $\times$ TAT hybrid carp (Table 3 ). Almost all essential amino acids, i.e. Thr, Ile, Leu, Phe, Met $(P<0.01)$ and His $(P<0.05)$ as well as non-essential Ser $(P<0.01)$ were more abundant in male fillet proteins than in fillets of female carp. As a result, higher $(P<0.01)$ levels of EAA sum $\left(93.6 \pm 2.25 \mathrm{~g} \cdot \mathrm{kg}^{-1}\right)$ were found in ROP $\times$ TAT males than in females $(81.3 \pm$ $\left.4.35 \mathrm{~g} \cdot \mathrm{kg}^{-1}\right)$. In experimental mirror carp groups, only isolated differences in amino acid levels were found. Fillets of pure line M2 males contained less $\operatorname{Ser}(P<0.01)$, fillets from mirror carp M2 $\times$ DOR70 males contained more $\operatorname{Arg}(P<0.01)$, and M $2 \times$ M72 mirror carp showed a difference in total amino acids $\mathrm{EAA}_{\text {sum }}$ in dependence on $\operatorname{sex}(P<0.01)$.

\section{Discussion}

Amino acid composition of fish muscle tissue is fairly stable for specific fish species (Kim and Lall 2000). Amino acid profiles of fillet protein in our experiment were similar to those reported for carp (Schwarz and Kirchgessner 1988; Fu et al. 2000; Buchtová et al. 2007a). Due to the genetic specification of the carp groups monitored, differences in the composition of specific amino acid and their total amounts were found especially between the scaly control $($ ROP $\times$ TAT) and the pure line M2. Fillets of other two experimental hybrids $(\mathrm{M} 2 \times \mathrm{L} 15, \mathrm{M} 2 \times$ DOR70) differed from ROP $\times$ TAT carp fillets in their quantities

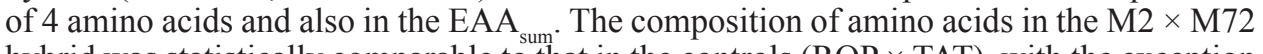
hybrid was statistically comparable to that in the controls $(\mathrm{ROP} \times \mathrm{TAT})$, with the exception of the non-essential Glu $(P<0.01)$. In all the cases mentioned, higher amino acid values were found in the hybrid controls ROP $\times$ TAT (Table 2).

According to $\mathrm{Fu}$ et al. (2000), these differences may be related to changes in genetic information on the basis of which muscle proteins are synthesized. The origins of F1 parents of the ROP $\times$ TAT hybrid are very distant (ROP: Russia, TAT: Hungary) and might hypothetically 


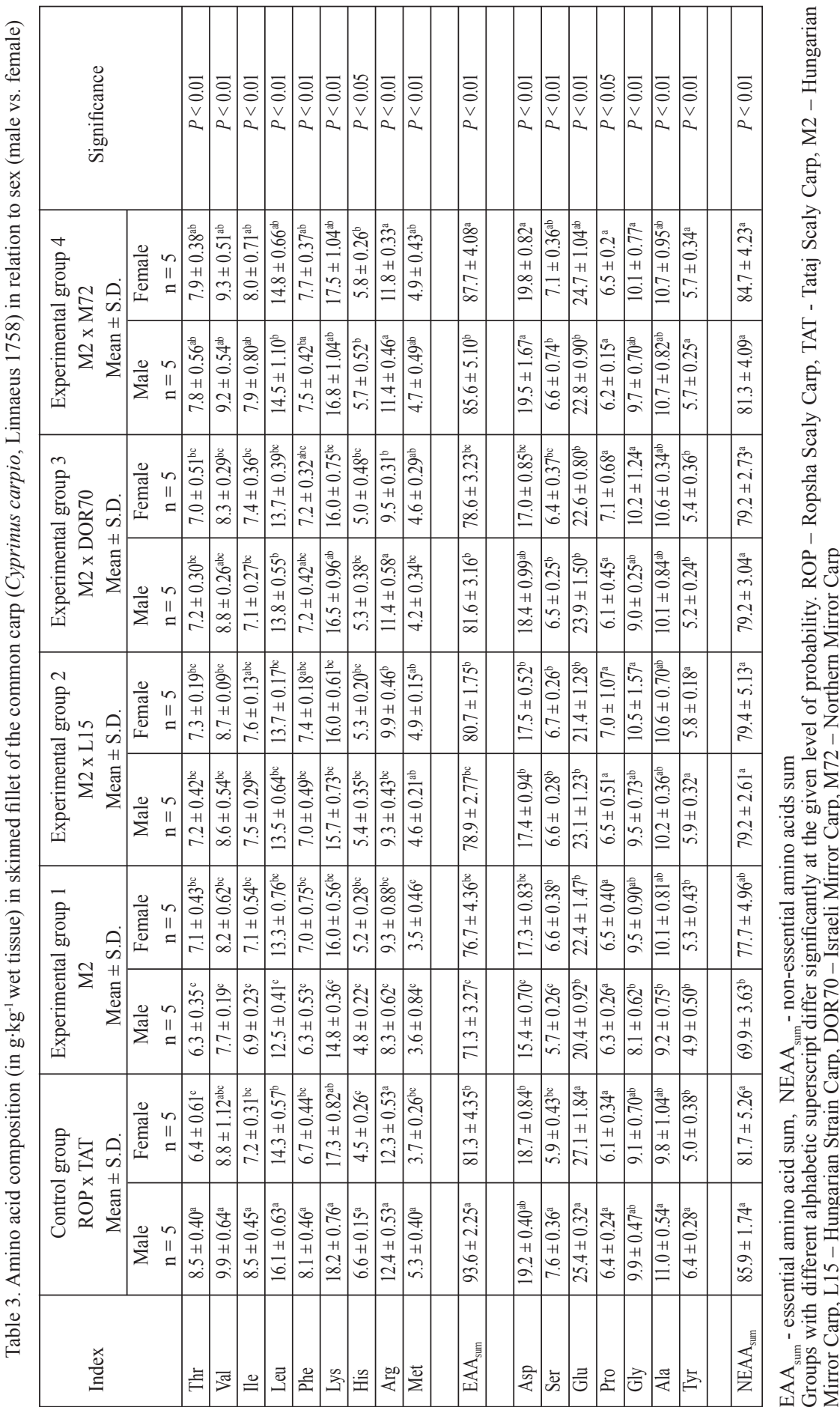


be the reason for differences in the amino acid composition, especially compared to the pure M2 line, whose origin is genetically identical (Hungary). In our experiment, however, differences in the amino acid composition will more probably be connected with earlier onset of sexual maturity in males (Table 1). Sex dependence was demonstrated mainly in scaly hybrid ROP $\times$ TAT, especially in terms of their essential amino acid composition (Table 3). The differences found are probably linked with a higher production of sex hormones of steroid nature in sexually mature males that positively affect anabolic biochemical processes and enhance proteosynthesis of muscle proteins and thus also the abundance of certain amino acids. Higher levels of these amino acids in fillets of ROP $\times$ TAT male carp were the reason for their higher representation in ROP $\times$ TAT carp fillets with no sex differentiation, and, consequently, the reason for the differences demonstrated in amino acid composition in relation to the genetic specification in the carp groups studied (Table 2).

Another hypothetical reason for the differences ascertained in amino acid composition might be different chemical composition of the diet fed to the fish with regard to the nutrient composition (protein and its constituent amino acids), or differences in nutrient requirements. According to Jobling (1994), nutritional requirements of fish of the same age reared in the same environment and under the same feeding regime are influenced by their size and degree of sex maturity. Akiyama et al. (1997) reported that variations in amino acid requirements of different species possibly reflect true differences between phylogenetically distinct families or species. In view of differences found in growth rates between individual groups (Table 1), unequal intakes of plant and animal protein (especially essential amino acids) may have ensued as a result of trophic competition. According to Limin et al. (2006) no fish can grow or reproduce without a continuous supply of protein. Metailler et al. (1981) demonstrated that the content of essential amino acids is the principal factor in their dietary value. Growth and food conversion efficiencies can be maximized by manipulating the composition of the dietary amino acids. However, Yamamoto et al. (2000) published that not only dietary protein levels and amino acid profiles, but also dietary fat levels influence tissue amino acids levels.

In view of the results presented, the only hybrid comparable to the ROP $\times$ TAT control with regard to amino acid composition (except Glu) is the M2 $\times$ M72 hybrid. Fillets of other experimental groups $(\mathrm{M} 2, \mathrm{M} 2 \times \mathrm{L} 15, \mathrm{M} 2 \times$ DOR70) contained generally less amino acids. In terms of sex differences (female carp v. male carp), fillets of male ROP $\times$ TAT controls showed the greatest abundance of essential amino acids, amino acid compositions in fillets of male and female mirror carp were practically the same.

\section{Hodnocení složení aminokyselin ve filetech lysých hybridů kapra obecného (Cyprinus carpio Linnaeus, 1758)}

Cílem práce bylo sledovat zastoupení aminokyselin $\mathrm{v}$ bílkovinách filetu u nově vyšlechtěných lysých linií kapra obecného. K pokusu bylo použito plemeno mad'arského lysce (M2) na mateřské pozici. Na něj byli křriženi mlíčáci jiných plemen (vrcholové kř́žžení). Byli to mad'arský lysec (M2) pro produkci čistého plemene, mad'arská lysá linie (L15), izraelské plemeno (DOR70) a severský lysý kapr (M72). Jako kontrola sloužil šupinatý hybrid ropšínského (ROP) a tatajského plemene (TAT). S ohledem na genetickou specifikaci sledovaných skupin kapra byly zjištěny četné rozdíly $(P<0.01$ resp. $P<0.05)$ v zastoupení konkrétních aminokyselin (EAA: Val, Leu, Lys, Arg, Met; NEAA: Asp, Glu, Tyr) a jejich celkových množství (EAA ${ }_{\text {sum. }}$, NEAA $_{\text {sum }}$ ) mezi šupinatou kontrolou (ROP $\times$ TAT) a čistou linií M2. Vyšší hodnoty aminokyselin byly zjištěny u kontrolních hybridů. Zastoupení aminokyselin ve svalovině filetu experimentálních lysců $(\mathrm{M} 2 \times \mathrm{L} 15, \mathrm{M} 2 \times$ DOR70) bylo prakticky stejné. Ve srovnání s kontrolou (ROP $\times$ TAT) obsahovaly tyto skupiny kapra méně $(P<0.01)$ Leu, Lys, Arg a Glu. Statisticky srovnatelné zastoupení aminokyselin s kontrolou (ROP $\times$ TAT) bylo zjištěno pouze u hybrida M2 $\times$ M72 s výjimkou 
Glu, kterého tento hybrid obsahoval méně $(P<0.01)$. V závislosti na pohlaví (jikernačky vs. mlíčáci) obsahoval nejvíce esenciálních aminokyselin filet samců kontroly ROP $\times$ TAT, u lysců bylo zastoupení aminokyselin ve filetech obou pohlaví prakticky stejné.

\section{Acknowledgements}

This experimental study was supported by the Ministry of Education, Youth and Sports of the Czech Republic (Research Plan MSM6215712402 and MSM6007665809).

The authors are grateful to Professor Straková, Ph.D. from the Institute of Nutrition and Dietetics of Farm Animals (Faculty of Veterinary Hygiene and Ecology of the University of Veterinary and Pharmaceutical Sciences Brno) for making qualitative and quantitative determinations of amino acids by HPLC.

\section{References}

Akiyama T, Oohara I, Yamamoto T 1997: Comparison of essential amino acid requirements with A/E ratio among fish species. Fish Sci 63: 963-970

Buchtová H, Svobodová Z, Kocour M, Velíšek J 2006a: Evaluation of growth and dressing out parameters of experimental scaly crossbreds in three-year-old common carp (Cyprinus carpio, Linnaeus 1758). Aquac Res 37: 466-471

Buchtová H, Svobodová Z, Kocour M, Velíšek J 2006b: Evaluation of the dressing percentage of 3-year-old experimental scaly crossbreds of the common carp (Cyprinus carpio, Linnaeus 1758) in relation to sex. Acta Vet Brno 75: 123-132

Buchtová H, Svobodová Z, Kocour M, Velíšek J 2007a: Amino acid composition of edible parts of three-year-old experimental scaly crossbreds of common carp (Cyprinus carpio, Linnaeus 1758). Aquac Res 38: 625-634

Buchtová H, Svobodová Z, Křížek M, Vácha F, Kocour M, Velíšek J 2007b: Fatty acid composition of flesh of three-year-old experimental scaly crossbreds of common carp (Cyprinus carpio, Linnaeus 1758). Acta Vet Brno 76: S73-S81

Buchtová H, Svobodová Z, Kocour M, Velíšek J 2008: Comparison of the amino acid contents in fillets, ovaries, testes and hepatopancreas of three-year-old experimental scaly crossbreds of common carp (Cyprinus carpio, Linnaeus 1758). Acta Aliment 37: 311-322

Davídek J, Hrdlička J, Karvánek M, Pokorný J, Seifert J, Velíšek J 1977: Laboratory guide of food analyses (In Czech). SNTL Praha, p. 189.

Fu C, Cui Y, Hung SSO, Zhu Z 2000: Whole-body amino acid pattern of $\mathrm{F}_{4}$ human growth hormone gene-transgenic red common carp (Cyprinus carpio) fed diets with different protein levels. Aquaculture 189: 287-292

Gela D, Rodina M, Linhart O 2003: Top-crossing with evaluation of slaughtering value in common carp (Cyprinus carpio L.) offspring. Aquac Int 11: 379-387

Gela D, Linhart O 2000: Evaluation of slaughtering value of common carp from diallel crossing. Czech J Anim Sci 45: $53-58$

Ježek F, Buchtová H 2007: Physical and chemical changes in fresh chilled muscle tissue of common carp (Cyprinus carpio L.) packed in a modified atmosphere. Acta Vet Brno 76: S83-S92

Jobling M 1994: Fish Bioenergetics. Chapman and Hall, London, p. 309.

Kim JD, Lall SP 2000: Amino acid composition of whole body tissue of Atlantic halibut (Hippoglossus hippoglossus), yellowtail flounder (Pleuronectes ferruginea) and Japanese flounder (Paralichthys olivaceus). Aquaculture 187: 367-373

Kocour M, Gela D, Rodina M, Linhart O 2005a: Testing of performance in common carp Cyprinus carpio L. under pond husbandry conditions I: top-crossing with Northern mirror carp. Aquac Res 36: 1628-1628

Kocour M, Linhart O, Gela D, Rodina M, Flajšhans M 2005b: The slaughtering value of all-female and bisexual populations of common carp (Cyprinus carpio L.) cultured in pond conditions of the Central Europe. Aquaculture 247: 20-21

Kocour M, Mauger S, Rodina M, Gela D, Linhart O, Vandeputte M 2007: Heritability estimates for processing and quality traits in common carp (Cyprinus carpio L.) using a molecular pedigree. Aquaculture 270: 43-50

Limin L, Feng X, Jing H 2006: Amino acids composition difference and nutritive evaluation of the muscle of five species of marine fish, Pseudosciaena crocea (large yellow croaker), Lateolabrax japonicus (common sea perch), Pagrosomus major (red seabream), Seriola dumerili (Dumeril's amberjack) and Hapalogenys nitens (black grunt) from Xiamen Bay of China. Aquac Nutr 12: 53-59

Linhart O, Gela D, Rodina M, Šlechtová V, Šlechta V 2002: Top-crossing with paternal inheritance testing of common carp (Cyprinus carpio L.) progeny under two altitude conditions. Aquaculture 204: 481-491

Metailler R, Aldrin JF, Messager JL, Mevel G, Stephan G 1981: Feeding of European sea bass Dicentrarchus labrax: role of protein and energy source. J World Maricult Soc 12: 117-118

Schwarz FJ, Kirchgessner M 1988: Amino acid composition of carp (Cyprinus carpio L.) with varying protein and energy supplies. Aquaculture 72: 307-317

Yamamoto T, Unuma T, Akiyama T 2000: The influence of dietary protein and fat levels on tissue free amino acid levels of fingerling rainbow trout (Oncorhynchus mykiss). Aquaculture 182: 353-372 